Article

\title{
Developments in Risk Management in Islamic Finance: A Review
}

\author{
Naseem Al Rahahleh ${ }^{1, *(\mathbb{D}, \text { M. Ishaq Bhatti }}{ }^{2}$ and Faridah Najuna Misman ${ }^{3(\mathbb{C}}$ \\ 1 Department of Finance, Faculty of Economics and Administration, King Abdulaziz University, Jeddah 21589, \\ Saudi Arabia \\ 2 La Trobe Business School, La Trobe University, Melbourne, VIC 3086, Australia; i.bhatti@latrobe.edu.au \\ 3 Department of Finance, Faculty of Business and Management, Universiti Teknologi MARA, 85000 Segamat, \\ Johor, Malaysia; farid978@johor.uitm.edu.my \\ * Correspondence: nalrahahleh@kau.edu.sa; Tel.: +966-565-2000
}

Received: 4 January 2019; Accepted: 12 February 2019; Published: 20 February 2019

check for updates

\begin{abstract}
The purpose of this study is to review recent developments pertaining to risk management in Islamic banking and finance literature. The study explores the fundamental features of risks associated with Islamic banks (IBs) as compared to those associated with conventional banks (CBs) in order to determine the extent to which IBs engage in effective risk mitigation. The study includes a consideration of the major studies in which the fundamental features of Islamic banks and finance (IBF) and the main characteristics of risk management in IBs are analyzed in comparison with those of CBs. Specifically, these two kinds of banks are compared in relation to the types of risks faced, the characteristics of those risks, and the nature and extent of exposure to those risks. A tabular methodology approach is used in concert with a comparative literature review approach for the analysis. The results show that there is weak support for Shariah-based product development due to the lack of risk mitigation expertise in IBs. The conclusion presented is that in comparison with CBs, IBs are more risk-sensitive due to the nature of their products, contract structure, legal costing, governance practices, and liquidity infrastructure. Furthermore, the determinants of the credit risk of Islamic banks in Malaysia (MIBs) are examined. Overall, bank capital and financing expansion have a significant negative impact on the credit risk level of IBs in Malaysia.
\end{abstract}

Keywords: Islamic banks; conventional banking; risk mitigation; Shariah jurisdiction

\section{Introduction}

Since its inception, the banking industry-whether conventional banks (CBs) or Islamic banks (IBs) - has focused on risk-return trade-off activities. Both types of financial institutions serve as intermediaries between borrowers and lenders and provide avenues through which clients can invest and/or save their money. Through borrowing, lending, saving, joint venture, and investment activities, banks take commissions, charge fees, and thus make profits. In recent decades, banking services have expanded considerably, by for example providing credit to individuals and business entities. On this basis, the structure of various types of risks has become more complex. A bank's main function is to receive money from individuals and firms who have money they do not need immediately (depositors) and then channel it to clients who need the money (entrepreneurs) for diverse projects that are subject to various types of risks. These clients include individuals, partnerships, joint ventures, and/or corporations that are either privately/family owned or publicly listed on the stock exchange (Lucia and Peters 1993). Due to the development of the international financial market in recent decades, banks now offer services that extend beyond the relatively straightforward activities associated with depositors and borrowers to encompass the complicated investment avenues of financial institutions, 
markets, and financial planning. CBs have become one-stop financial centers offering a complete range of financial services to local and international clients. Most of the risk associated with these services is transferred to depositors and investors without due regard to the nature of either the risk or the investment venue. The purpose of the present study is to review various types of risks associated with the financial industry, particularly as they relate to IBs.

In general, the financial industry provides efficient services to clients although most of these services are interest-based and interest (Riba)-bearing. However, financial services of this kind are prohibited under Islam due to the religion's original tenets and the ethical sensitivities of some sections of the wider Islamic community. Given that this is the case, many Muslims seek interest-free (without usury) financial transactions and an ethical approach to banking services. For example, more than 1.5 billion Muslims worldwide do not participate in interest-based banking systems due to the prohibition of interest in Islamic jurisprudence, i.e., Shariah. Faithful Muslims believe that clear regulations are revealed by God to the Prophet Muhammad (PBHU) in the Quran, according to which all business transactions should be free from Riba (interest) (Lewis 2011).

The Quran clearly states the prohibition of Riba in any business transaction. Shariah permits trade and, therefore, all Islamic Banks and Finance (IBF) products and services are based on either profit loss sharing (PLS) or other risk-sharing joint ventures. Riba is prohibited so that fair financial transactions can take place in line with the objectives of the Islamic banking system. This Riba-free financial system is an avenue through which all Muslims can conduct their financial transactions according to Shariah law. Regulated under Shariah, the IBF industry is based on five fundamental principles: (i) interest-free; (ii) ethical financial activities_ halal (permissible); (iii) asset-based and asset-backed; (iv) partnership investments based on PLS between the financer and the entrepreneur; and (v) risk-sharing.

There are diverse reviews in the literature focused on multiple issues as they relate to IBs and CBs in various jurisdictions. These reviews cover topics such as the differences and similarities between IBs and CBs in terms of performance measures, bank size, corporate governance, and risk. Some recent examples are Cerović et al. (2017), Sun et al. (2017), Khan et al. (2018), Salih et al. (2018), and Hassan and Aliyu (2018). The most comprehensive review briefly covering all areas of IBs and CBs is presented by Hassan and Aliyu (2018). The objective of the present paper is to review the literature in the area of risk management, the features of risks and risk mitigation in IBs relative to CBs. Moreover, major differences between IBs and CBs in relation to risk-return complexities are examined. Our research also contributes to the literature through a review of major studies that analyze the fundamental features of IBF and the main characteristics of risk management in IBs compared to CBs. Further, IBs and CBs are compared in relation to the risks faced by IBs, the characteristics of those risks, and the nature and extent of the banks' relative exposure to them. A new framework is proposed for classifying risks in which the reality of market risk and unique risk is taken into account. Moreover, we investigate the determinants of the credit risk of Islamic banks in ASEAN countries via an empirical study employing data from Malaysian Islamic banks. We conclude that bank capital and financing expansion have a significant negative impact on the credit risk level of IBs in Malaysia.

The remainder of this paper is structured as follows: In Section 2, we provide a detailed description of the IB industry including its history, structures, and types of contracts, and a comparison between IBs and CBs is also offered. We present a detailed discussion of the risks involved in banking and the risk management strategies used to mitigate them, particularly in regard to IBs, in Section 3. In Section 4, the determinants of credit risk for IBs in Malaysia (MIBs) are identified and considered. Section 5 concludes the study with a summary of the main themes covered and a consideration of the implications of the results reported. 


\section{Islamic Financial Institutions (IFIs)}

\subsection{History of Islamic Financial Institutions (IFIs)}

The history of Islamic finance and Islamic Financial Institutions (IFIs) is more than a thousand years old, and during much of that time there were no major financial crises in Muslim-ruled territories in Asia, Europe, and Africa. However, in the recent past, the IBF industry has changed dramatically, due to several historical processes: the colonization of Muslim lands, which began with the rise of the European empires, such as the reconquest of Spanish Muslim territories by 1492; the overthrow of the Mughals in India in 1857; the "scramble for Africa" in the nineteenth century by the emerging European colonial empires; and the division of the Ottoman Empire's Arab territories as a result of the Sykes-Picot Agreement in 1915. The colonial era more or less came to an end after World War II, when Britain and then France withdrew from the majority of their colonial Muslim territories. The modern-day history of IBs and/or IFIs begins when formerly colonized Islamic countries became independent after World War II. Given this history, we can divide the history of IBF into two phases: the early days of IFI transactions and modern-day experiments and developments.

The first period starts from the time of the Prophet Muhammad (PBUH) including the period of the Orthodox Caliphate, the noble companions and the succeeding generations up to and including the Umayyad and Abbasid Eras. The second period, which encompasses modern-day IBF, actually began during the nineteenth century. The timeline is given in detail for the second period in Figure 1, incorporating IBF and IFI activities from 1962 to 2016.

Modern conventional banking in the Islamic world began in Egypt and India. In the 1890s, during the Ottoman Empire, Barclays Bank opened its first branch in Cairo, which immediately drew serious criticism from Islamic scholars about the interest-based nature of the financial transactions taking place there. Barclays closed the branch as a result. A similar incident occurred in British India where Islamic scholars resisted interest-based financial transactions by issuing a unanimous Fatwah (decree or religious ruling), which led to the birth of IBF during the 1940s. India's Muslims avoided dealing with these banks and instead sought alternative interest-free savings and loan societies, which began operating in pre-partition India. After 1947, these societies spread to newly born Pakistan. However, the development of IFIs was very slow due to a lack of trust on the part of both the general public and governments due to the absence of any formal regulatory body.

In 1975, about 35 years after the introduction of interest-free savings and loan institutions to the Indian subcontinent, Dubai Islamic Bank began operating as the first IFI for the private corporate sector. Since then, IFIs have expanded globally to both Muslim and non-Muslim countries. The fast growth of IFIs was strongly supported by Muslims who thirsted for Islamic products and services. Today, these institutions offer an extensive portfolio of products and services, including Islamic "windows," Islamic investment banks and funds, Islamic mortgage companies, Takaful (Islamic insurance) companies and Mudharabah (profit-sharing) companies (Iqbal and Mirakhor 2007). IFIs are constantly growing both in number and in terms of the types of services offered in response to a high level of demand. However, according to Laldin (2008), in certain countries, IFIs are quite limited due to a lack of expertise and Shariah-compliance issues. For example, the weak legal and tax framework, which stymies the development of a viable Islamic financial market.

There are at least five types of IFIs, of which IBs constitute the first and most established Islamic institutions operating according to Shariah principles. In certain countries, various products and services are offered through an Islamic window established at CBs that are non-fully-fledged IBs. This Islamic window located in a CB is defined as a special arm operating within conventional banking groups. This arm offers Shariah-compliant products and services that are similar to those offered by IBs but with a limited product range. The Islamic window is a stepping stone to a fully-fledged IB. For example, in Malaysia in reference to the CB industry operating there, Bank Negara Malaysia (BNM) began offering Shariah-approved products and services in 1993 through the Islamic window, which is also known as an Interest-Free Banking Scheme (IFBS). 


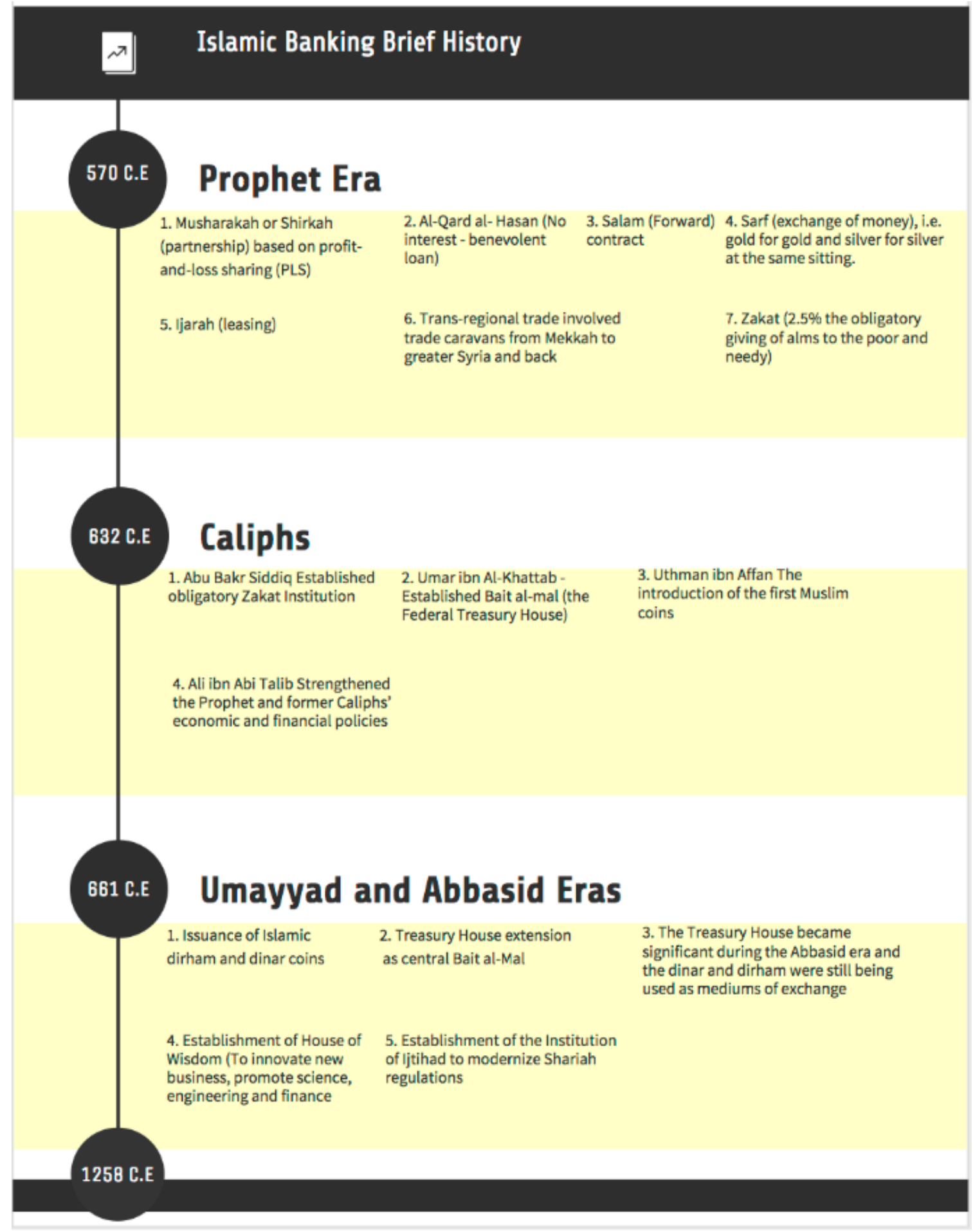

Figure 1. Islamic banking history timeline.

\subsection{Definitions and Structure of IFIs}

There are various definitions of IFI and IBF in the literature. For example, Khir et al. (2008) define IBF as financial institutions in which the objective is to implement the economic and financial principles of Islam. However, a few scholars have considered IB to be an alternative to the CB system as practiced in Western countries (Akkizidis and Khandelwal 2008). Moreover, Archer and Karim (2009) argue that an IB is a company that acts as a financial intermediary between depositors and borrowers in order to connect the supply and demand of funds. IBs also provide other banking services similar to those 
provided by CBs. The Organization of Islamic Cooperation (OIC) defines an IB as a financial institution whose statutes, rules, and procedures expressly state its commitment to the principles of Shariah and to the banning of the receipt and payment of interest in any of its operations. The Malaysian Islamic Banking Act of 1983 defines an IB as a company that conducts Islamic business, i.e., a banking business whose aims and operations do not involve any element not approved by the religion of Islam. To this end, even other religious groups support the ethics and practices of IBF. For example, the Vatican has stated that Islamic finance could help Western banks in times of crisis.

IBs were established in order to (i) promote, foster, and develop banking services and products based on Islamic principles; (ii) contribute to Islamic economic development; and (iii) ensure the best allocation of resources and create equality in the distribution of wealth. IBs were established to help people regardless of their circumstances or personal characteristics, e.g., the extent of their wealth, their community or society, or their beliefs. The operations of IBs are based on Shariah principles. What primarily differentiates IBs from CBs is that neither Riba (interest), Gharar (uncertainty), nor Maysir (gambling) feature in the operations of IBs. Riba, which refers to interest charged on loans or received from investments, is prohibited under Islamic law and considered haram (non-permissible). According to Shariah principles, IBs are not allowed to incur any fees for transactions or receive any interest. The second prohibition that applies to IBs is Gharar, which can be defined as undertaking a venture blindly without sufficient knowledge or engaging in excessively risky transactions. In IB contracts, all the terms should be specific and clearly explained, although minor uncertainty can be permitted when necessary. The last prohibition in Islamic banking is Maysir, which refers to the acquisition of wealth by chance, no matter whether or not it deprives another party's right or any game of chance (Ayub 2007). Examples are buying a lottery ticket, winning the lottery, making futures transactions, and engaging in short selling.

The IB system promotes profit- and risk-sharing-a practice designed to render financial transactions fair to all the parties involved. An IB can invest a depositor's money in permissible businesses to earn a variable return, which can be shared with depositors through an agreed PLS contract. Unlike CBs, the rate of return is not fixed in the early investment period. It is only known at the end of the investment period, which promotes fairness in financial matters, as IBs share actual returns with investors. The five most important pillars of Islamic banking (Ayub 2007; Khir et al. 2008) can be summarized as follows:

i. Prohibition of Riba (interest): Under Shariah, Muslims are strictly prohibited from any involvement in Riba-based activities, whether in terms of paying interest or receiving it.

ii. Sharing of Equity Contribution: As Riba is prohibited in Shariah, IB operations are based on equity contributions. The supplier of a fund (investor) and the borrower (entrepreneur) are required to share the profit and risk arising from the transaction. This kind of PLS contract is at the heart of IFI.

iii. Money is considered a medium of exchange: In Islam, money cannot generate money on money. Instead, money should be treated as capital and any profit/loss must be shared between parties as per the proportion of their investments. All such transactions must be backed by assets.

iv. Gharar: Excessive uncertainty and speculation must be avoided because these lead to Maysir (gambling), which is prohibited.

v. The purity of contract: Under Shariah, IFI contracts should have clear disclosure in order to reduce the risk of exposure to the contract. This means strict sanctity of contracts is required in IFI transections.

All IFI contracts should be based on the five pillars. In fact, failure to adhere to any one pillar renders an IBF contract void. For example, in a sales contract, the asset (good) must exist and be permissible according to Shariah, and the selling price should not include Riba.

In IB operations, all products and services are offered based on three main types of contracts:

(i) trading contracts, (ii) participation contracts, and (iii) supporting contracts (Khir et al. 2008). 
Participation contracts are based on a PLS agreement, whereas trading and supporting contracts are also known as non-profit and loss-sharing (NPLS) contracts. Hanif and Iqbal (2010) argue that a participation contract is a Shariah-based product, whereas trading and supporting contracts are Shariah-compliant products. In trading and supporting contracts, returns are predetermined and fixed subject to Shariah constraints whereas, in Shariah-based products, returns are not predetermined. Shariah-based products entail establishing a fixed agreed sharing ratio for PLS in advance. Table 1 summarizes the types of contracts (Iqbal 2011) offered by IFIs and IBs.

Table 1. Types of Financial Contracts Currently Offered by Islamic Banks.

\begin{tabular}{llll}
\hline \multicolumn{1}{c}{ Trading Contract } & & Participation Contract & \multicolumn{2}{c}{ Supporting Contract } \\
\hline (i) Istisna & & & (i) Al-Rahnu \\
(ii) Ijarah & & & (ii) Al-Kafalah \\
(iii) Bai-Bithaman Ajil & (i) Musharakah & (iii) Qard Al-Hasan \\
(iv) Bai-Inah & (ii) Mudharabah & (iv) Hiwalah \\
(v) Murabahah & (iii) PLS: Profit/loss sharing & (v) Tabarruu' \\
(vi) Salam-forward & & & (vi) Hibah \\
(vii) Wadiah & & & (vii) Ibraa' \\
\hline
\end{tabular}

The prohibition against Riba does not prevent Muslims from engaging in trade based on PLS and thereby realizing profits from participation (equity), supporting (fee), or trading (cost-plus) contracts. According to Ariff (1988), although Islamic law forbids the imposition of interest, this does not mean that capital is without cost in Islamic banking, rather the cost incurred by the borrower is a factor of production in Islamic law.

Profit-sharing contracts constitute a viable alternative to replacing the function of interest (Kahf 1999). One example of this kind of contract is Mudharabah or trust financing under the participation (equity) contract. In this type of contract, the IB provides capital (Rabb ul-mal) and the user of the capital is the entrepreneur (trustee of the venture). The profit to be realized is predetermined based on an agreed ratio, and any loss is borne by the IB. Further, although this is the case, the IB has no say in how the entrepreneur runs the business thus funded. The second type of participation contract is Musharakah. Here, both parties, i.e., the IB and the entrepreneur, contribute capital investment and share profit/loss as per an agreed ratio. IBs oversee the investment in order to foster profitability (Samad et al. 2005). Some of these traits do not exist in CBs.

When IBs began operating in countries where CB services are offered, they began with trading or cost-plus principles, which though Shariah compliant does not entail a Shariah-based product. Under a trading contract, products are offered based on cost-plus or mark-up principles. That is, an IB purchases a given asset in exchange for a negotiated profit margin (Samad et al. 2005). In this case, the Murabahah contract is the best example of a cost-plus-profit margin in which IBs purchase an asset on behalf of the entrepreneur and later resell the asset back to the entrepreneur at a predetermined price. The resale price includes the cost and profit margin agreed to by both parties. The entrepreneur can choose to repay the IB either in the form of a lump sum or installments. IBs also offer products and services based on the supporting contract under which a small fee may or may not be charged to process the contract. For example, Qard Al-Hasan (benevolence financing), no fee is charged to the customer.

All types of contracts in Islamic banking are unique, accepted worldwide, and growing faster than contracts offered by CBs. Currently, IFIs dominate the industry in oil-producing countries (Iran, followed by Saudi Arabia and the GCC countries) with the exception of Malaysia, which is ranked third. In GCC countries, the country with the fastest growing IFI sector is the UAE, where this sector is expected to reach US $\$ 265$ billion by the end of 2019. This will make the UAE the fourth largest IFB market by value. Currently, there are nine IBs in the UAE with overseas branches catering to the needs of halal finance for Muslim minorities. The Omani IBF industry is new compared to the IBF in the rest of the GCC countries. Six banks offer IBF products, among which are Al Noor, Al Izz 
Islamic Bank, and Dubai Islamic Bank. However, IBF windows and other services are provided by Bank Nizwa, Bank Muscat, and the National Bank of Oman. Yet, faithful Omanis prefer to conduct their Shariah-compliant banking across the border in the UAE.

\subsection{Conventional Banks vs. Islamic Banks}

According to Abedifar et al. (2015, p. 637), "Apart from key exceptions, the empirical literature suggests no major differences between Islamic and conventional banks in terms of their efficiency, competition and risk features." In fact, IBs are operationally similar to $\mathrm{CBs}^{1}$ with the exception of Shariah compliance. In addition to the differentiation between products and services, the composition of sources and uses of funds in IBs also differ from those of CBs. For IBs, income is derived from savings accounts, current accounts, and restricted or unrestricted investment accounts. All four sources of income are based on Al-Wadiah and Mudharabah contracts. These funds can be used in PLS or Non-PLS contracts. The depositors or investors are the shareholders and receive a return if a profit is made but also share equally with borrowers any losses. Unlike with CBs, the investment return is unknown at the beginning of the contract. However, the ratio of profit sharing and loss is determined in advance and agreed to by both parties. Consequently, IBs offer depositors the opportunity to invest in a few products suited to their investment objectives.

The financial statements for IBs differ from those of CBs with just a few exceptions. For example, fixed assets and shareholder equity, cash in IBs are strictly for cash items only, whereas cash in CBs usually consists of cash and other interest-bearing assets such as treasury bills. The differences between CBs and IBs in terms of financial statements are presented in Table 2. A comparison of the respective banks' features is presented in Table 3. To ensure that they operated in compliance with Shariah, IBs in Malaysia (MIBs) were regulated initially by the Islamic Banking Act (IBA) of 1983 and overseen by Bank Negara Malaysia (BNM). However, the BNM introduced the Takaful Act in 1984 and the Islamic Financial Services Act (IFSA) in 2013. Further, the BNM set out the IFSA with the goal of promoting financial stability and compliance with Shariah law. Under both statutes, all IBs are required to have a Shariah Supervisory Board (SSB), which plays a major role in advising management on Shariah-related issues. In fact, all products and services must be approved by the SSB. In a study on the impact of the SSB on risk based on a sample of 102 Islamic banks in 28 countries, Safiullah and Shamsuddin (2018) found operational and insolvency risks in Islamic banks decline with an increase in SSB size and the proportion of SSB members with higher academic qualifications but increase when the proportion of SSB members with reputation is higher.

Table 2. A Comparison of the financial statements of conventional banks (CBs) and Islamic banks (IBs).

\begin{tabular}{|c|c|}
\hline Conventional Bank (CB) & Islamic Bank (IB) \\
\hline $\begin{array}{l}\text { Assets } \\
\text { Cash and liquid assets (including treasury bills and notes) } \\
\text { Investments \& deposits } \\
\text { Loan portfolios } \\
\text { Fixed and other assets }\end{array}$ & $\begin{array}{l}\text { Assets } \\
\text { Cash and cash equivalents } \\
\text { Sales receivable (Murabahah and others) } \\
\text { Islamic financing assets including Mudharabah, } \\
\text { Musharakah, Ijarah, Istisna, and Salam } \\
\text { Fixed and other assets }\end{array}$ \\
\hline $\begin{array}{l}\text { Liabilities and Equity } \\
\text { Deposit (current \& saving accounts) } \\
\text { Promissory notes } \\
\text { Minority interest } \\
\text { Borrowing and other liabilities } \\
\text { Shareholders' equity }\end{array}$ & $\begin{array}{l}\text { Liabilities and Equity } \\
\text { Saving and current accounts } \\
\text { Salam and Istisna payables } \\
\text { Other liabilities (Zakat and tax payable) } \\
\text { Depositors' share of profit }\end{array}$ \\
\hline
\end{tabular}

1 Using a sample of 48 financial institutions in Malaysia for the period of 1995 to 2004, Chong and Liu (2009) examined whether Islamic banking is different from conventional banking. They found that Islamic banking is not very different from conventional banking in reference to the PLS paradigm, as financing is strictly PLS based in only a negligible portion of IBs in Malaysia. 
Table 3. Main differences between conventional banks (CBs) and Islamic banks (IBs).

\begin{tabular}{|c|c|c|c|}
\hline No. & Item & Conventional Bank (CB) & Islamic Bank (IB) \\
\hline 1 & Principle & Based on fully artificial principles. & Based on Shariah principles. \\
\hline & & & Free of the following prohibited elements: \\
\hline 2 & $\begin{array}{l}\text { Prohibited } \\
\text { elements }\end{array}$ & Not applicable. & $\begin{array}{ll}\text { 1. } & \text { Riba } \\
\text { 2. } & \text { Gharar } \\
\text { 3. } & \text { Maysir }\end{array}$ \\
\hline 3 & Risk sharing & $\begin{array}{l}\text { Investor is certain to receive a } \\
\text { predetermined rate of interest. }\end{array}$ & $\begin{array}{l}\text { Islamic banking promotes risk sharing } \\
\text { between the provider of capital (investor) } \\
\text { and the recipient of capital } \\
\text { (entrepreneur). }\end{array}$ \\
\hline 4 & Products & Not applicable & Shariah-compliant products. \\
\hline 5 & $\begin{array}{l}\text { Asset-backed } \\
\text { Financing }\end{array}$ & $\begin{array}{l}\text { Banks and financial institutions deal } \\
\text { in money and monetary papers only. }\end{array}$ & $\begin{array}{l}\text { Does not recognize money as a } \\
\text { subject-matter of trade. }\end{array}$ \\
\hline 6 & Moral dimension & $\begin{array}{l}\text { Not concerned about the moral } \\
\text { implications of the activities financed } \\
\text { and are not transparent. }\end{array}$ & $\begin{array}{l}\text { Works within the moral values of Islam, } \\
\text { cannot finance any projects that conflict } \\
\text { with Islam and promotes transparency. }\end{array}$ \\
\hline 7 & $\begin{array}{l}\text { Zakat } \\
\text { (religious tax) }\end{array}$ & Do not deal in Zakat. & It is compulsory to pay Zakat. \\
\hline 8 & Penalty on default & $\begin{array}{l}\text { Additional interest charged on default } \\
\text { payment. }\end{array}$ & No extra charge on default payment. \\
\hline 9 & $\begin{array}{l}\text { Customer } \\
\text { relationship }\end{array}$ & $\begin{array}{l}\text { Relationship between a bank and its } \\
\text { customers as a creditor and debtor. }\end{array}$ & $\begin{array}{l}\text { Status of a bank is in relation to its } \\
\text { customers as a partner, investor, and } \\
\text { entrepreneur. }\end{array}$ \\
\hline 10 & $\begin{array}{l}\text { Shariah Supervisory } \\
\text { Board (SSB) }\end{array}$ & Not applicable. & $\begin{array}{l}\text { Each Islamic bank must have a Shariah } \\
\text { Supervisory Board (SSB) to ensure all } \\
\text { business activities are in line with Shariah. }\end{array}$ \\
\hline
\end{tabular}

The differences, as outlined in Table 3, suggest that IBs may be exposed to different risks which require alternative risk management approaches.

In addition to the main differences between IBs and CBs, in a number of studies conducted a comparative analysis of performance measures and bank size between IBs and the CBs are reported. For example, El Massah and Sayed (2015) used six years of panel data to perform an empirical comparison of IBs and CBs in terms of their performance in the UAE. The researchers drew on the financial ratio using profitability, liquidity, solvency, and credit risk as a performance measure and observed that CBs outperformed IBs. However, Olson and Zoubi (2017) observed that IBs performed better than $\mathrm{CBs}$ did during the financial crisis.

In regard to bank size, Abedifar et al. (2013) argued that smaller IBs have lower credit risk and insolvency risk as compared to those of the CBs. They also observed that small IBs in majority Muslim countries had a lower credit risk than did small CBs. Further, Olson and Zoubi (2017) and Beck et al. (2013) concluded that large IBs are less profitable than small CBs.

\section{Risks in Banking}

Risk is defined as the measure of uncertainty associated with any given business activity, including banking (Oldfield and Santomero 1997). Hence, both IBs and CBs are exposed to risk in their daily operations. For example, interest rate volatility ${ }^{2}$ has an impact on the cost of funds and profits. According to Čihák and Hesse (2010), risk is simply a measure of uncertainty, the chance that some event will have an impact on objectives. In the case of banking operations, risk can result from the

2 Volatility is a measure of variations in the price of a financial instrument over a period of time. Interest rate volatility refers to the variability of interest rates on loans and savings over time. 
uncertainty of profit or loss in daily operations, such as deposits and loans. Risk can presage a major disaster for any financial institution including IBs. For this reason, it is critical that banks continuously define and identify the risks involved in their business activities.

In general, financial institutions are exposed to systematic and unsystematic risks, both of which have negative consequences for the institution's performance should it fail to manage operational risks effectively. Excessive risk exposure can negatively affect the profitability of a bank, thereby placing its future in jeopardy. The 2008 global financial crisis (GFC) brought with it a rapid fall in excessive risk-taking activities. Abedifar et al. (2015) found that in the wake of the GFC, the Islamic world showed an increased interest in risk in banking. Saunders and Cornett (2006) identified five risk categories: (i) credit risk, (ii) interest rate risk, (iii) liquidity risk, (iv) underwriting risk, and (v) operating risk. Others identified three kinds of risks: (i) credit risk, (ii) market risk, and (iii) operational risk (Apostolik et al. 2009; Basel 2003; Carey and Stulz 2005).

\subsection{Risk in Islamic Banking}

Iqbal and Mirakhor (2007) classified risk in IFIs into four major categories: financial risk, business risk, treasury risk, and governance risk. Financial risk refers to the possibility of incurring a direct financial loss of assets and liabilities, and it is one of the first risks to appear in a discussion about risk management policy. For IFIs, financial risk is unique due to the nature of the contract. IFIs face three types of financial risk — credit risk, market risk, and equity investment risk—whereas traditional financial institutions face only credit risk and market risk (Iqbal and Mirakhor 2007; Hassan et al. 2018).

Business risk is linked to business activities and the environment, as well as to any changes or movements in regard to macroeconomics or policy, legal and regulatory factors, and the financial sector's infrastructure, such as payment systems and the auditing professions (Greuning and Iqbal 2008). IFIs are also exposed to regular business risk similar to that experienced by conventional financial institutions. However, according to Iqbal and Mirakhor (2007), IFIs are exposed to one business risk in particular: the rate of return risk. Risk of insolvency is considered a business risk because a business risks becoming insolvent when its capital is insufficient to sustain its operations and neither a capital solution nor an operational solution is forthcoming.

In reference to treasury risk, IFIs face two types of risks: liquidity risk and hedging risk. The treasury risk is related to asset and liability management, short-term liquidity management, and cash and equity management. For IFIs, liquidity risk is considered one of the most critical risks due to: (i) the limited liability of the Shariah-compatible money market and inter-bank market; and (ii) the shallow nature of the secondary market for Islamic financial instruments. Ray (1995) identifies lack of liquidity as a major problem for IBs and states that there are two reasons for IBs to experience this problem: (i) a gap may exist between the central bank and the IB whereby the former refuses to provide funds on a basis other than interest lending, and (ii) the limited number of financial instruments accepted as Shariah-compliant.

Finally, IFIs are subject to governance risk, i.e., to risk arising from a failure on the part of the governing institution, negligence in conducting a business, and meeting contractual obligations and from a weak internal and external institutional environment. Governance risk includes legal risks whereby financial institutions are unable to enforce their contracts (Iqbal and Mirakhor 2007). Here, IFIs must deal with Shariah risk, whereas this is not an issue for conventional financial institutions.

We propose a framework for grouping the risks to which IBs are subject by drawing on, advancing, and adapting some of the key insights in the literature. Figure 2 illustrates the risk profile of IBs by presenting a systematic and unsystematic risk classification. In this framework, there are three risk groups: systematic, unsystematic, and a combination of the two called-systematic/unsystematic risks (SUR). In this new framework, the only kind of systematic risk is business risk. Governance risk, which consists of operational, reputation and Shariah risks, is classified under unsystematic risk. Financial risk and treasury risk are classified under SUR because these can be either systematic or unsystematic risks. 
Consisting of credit risk, market risk, and equity risk, financial risk derives both from external and internal sources. For this reason, financial risk cannot be classified entirely under either systematic or unsystematic risk. For example, credit risk is of a default payment by the borrower, but IBs operate as an entrepreneur/buyer in that they provide financing rather than just a standard loan. Therefore, IBs face a credit risk from possible changes in the economy generally, from specific market conditions, and from internal weaknesses in the banks. Under Shariah, an IB is either an investor or seller when it provides financing to customers. In this way, the IB can control its risk exposure when making decisions about providing any finance. Poor decisions will worsen the possibility of credit risk in the future. Further, risk has become a significant challenge for IBs in the current era of globalization. In order to ensure the survival of IBs in the finance market, effective risk management is essential to satisfy the financial needs of customers, remain in compliance with Shariah, and ensure the long-term future of the IB.

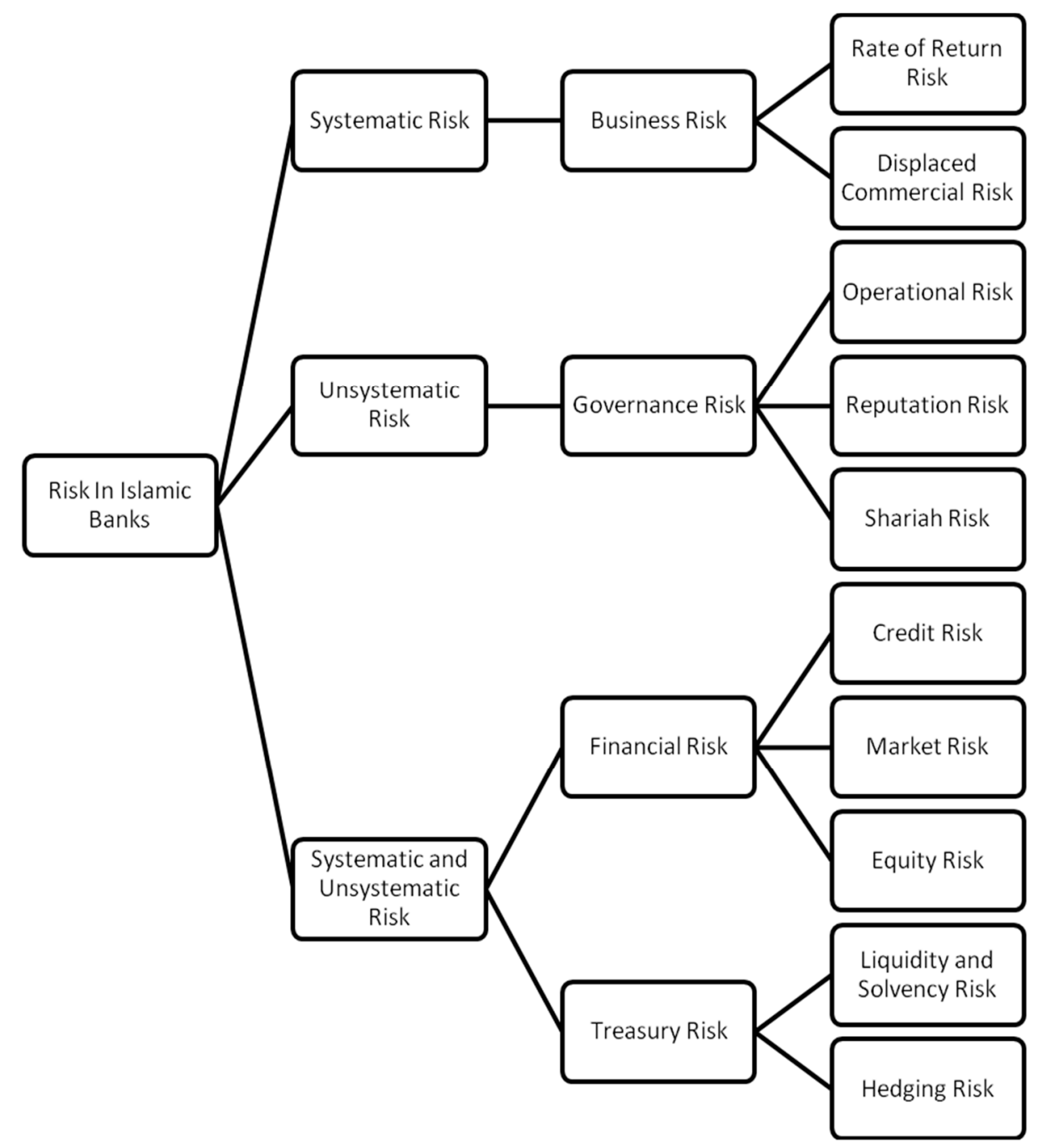

Figure 2. Classification of risks faced by IBs.

\subsection{Unique Nature of Risk in Islamic Banks (IBs)}

IBs are unique not only in terms of their principle of operations but also in relation to risk-related issues. For this reason, in a few early studies, researchers referred to the far-reaching effects of Shariah on banking operations to argue that IBs are subject to greater risk compared to conventional banks. This argument refers to applied research (Abedifar et al. 2013; Akkizidis and Khandelwal 2008; Čihák and Hesse 2010; Hassan and Dicle 2005; Sundararajan and Errico 2002). Ahmed and Khan (2007) 
contend that IBs face two types of risks: firstly, risks similar to those faced by CBs; and secondly, risks uniquely associated with Shariah compliance. According to Makiyan (2008), Shariah-related risk can be further classified as specific to IBs, e.g., risks related to PLS contracts, and general risks associated with IBs, e.g., legal, corporate governance, and market structures.

In two studies (Abedifar et al. 2013; Čihák and Hesse 2010), researchers identify various types of risks and explore the differences between IBs and CBs in this regard. Both research groups relied on data from Islamic Cooperation (OIC) member countries at the end of the 20th century into the first decade of the 21st century: Abedifar et al. (2013) used a sample of 24 OIC member countries for the years 1999-2009 whereas Čihák and Hesse (2010) used a sample of 20 OIC member countries for the years 1993-2004. In both studies, small IBs were found to have a lower default risk than did small CBs, and larger IBs were found to have a higher default risk where insolvency risk is higher. However, Beck et al. (2013) did not find differences in these kinds in a sample of banks from 141 countries for the period of 1995 to 2007. Furthermore, based on 20 countries for the period of 1995-2010, Pappas et al. (2014) showed that in comparison with CBs similar IBs have significantly lower failure rates. In a study by Saeed and Izzeldin (2016) for a sample of seven countries for the period of 2002-2010, default rates were reported as inversely related to profit efficiency for IBs, although the opposite was shown for their conventional counterparts.

The specific nature of risk and the unlimited number of ways in which a project can be financed using either profit- or loss-sharing or non-profit or loss-sharing contracts forces IBs to take more risks than CBS take (Sundararajan and Errico 2002). Deposit and lending activities as practiced by IBs are based on either the PLS or NPLS principle. The PLS principle promotes risk sharing between the lender of the capital and the borrower of that capital. The relationship between the bank and its customers is not a relationship only between a lender and a borrower, however. It is also a relationship between an investor and an entrepreneur. This principle of sharing is an equitable way to create wealth including by fostering fairer income distribution with a general goal of furthering the cause of economic justice and thus greater and more widespread prosperity (Rosly 1999). However, this situation invites a specific risk that cannot be avoided by IBs. For example, in Mudharabah financing, default on the part of the entrepreneur cannot be recognized until the contract has expired. Furthermore, IBs as the providers of capital does not have any legal control over either the entrepreneurs or the businesses thus financed. The non-profit and loss contract of financing also exposes IBs to significantly more risk than is the case for CBs. For example in Ijarah (leasing) financing, IBs do not have the option of transferring substantial risk and reward to the lessee because leased assets must be documented on the balance sheet of banks for the whole term of the lease (Makiyan 2008).

In regard to the risk involved in each type of contract used by IBs in taking deposits and providing financing, the main risks involved in equity-based financing (EBF) are credit and equity risks. In EBF, IBs are investors in a project proposed by an entrepreneur. In this arrangement, all parties share profits and losses as per an agreement. No collateral nor guarantee of any kind constitutes any part of EBF. All these factors expose IBs to more risks than is the case for CBs. In trading-based financing (TBF), IBs are exposed to credit, market, and Shariah risks. This type of financing contributes the largest proportion of the total financing in IBs, especially in Malaysia. This financing is based on cost-plus or buy-and-sell-back contracts. In most cases, an IB acts as the seller whereas the customers are the buyers of the given assets.

Sundararajan and Errico (2002) found that specific risks are attached to various non-PSLB (Profit-Sharing and Loss-Bearing) methods, for example, Salam and Ijarah. In regard to Salam, IBs are exposed to both credit and commodity price risks. In Ijarah, IBs bear all the risks until the end of the lease period, as unlike CBs, they cannot transfer ownership in lease contracts. Čihák and Hesse (2010) claim the uniquely extensive and multifaceted nature of the risks faced by IBs results both from the specific nature of the PLS and NPLS contracts and also from the legal, governance, and liquidity infrastructure of Islamic finance. These factors cause IBs to be more vulnerable to unfavorable events compared to conventional finance institutions. According to Akkizidis and Khandelwal (2008), 
the scarcity of hedging instruments, the undeveloped inter-bank money markets, and the market for government securities all limit the ability of IBs to handle the risks to which they are subject. IBs are constrained in using some risk mitigation instruments that their conventional counterparts use, for instance, options, futures, and forward instruments, which are not compatible with Shariah principles (Ahmed 2011). Additionally, IBs are prohibited from transferring risk through debt-selling activities, popularly known as credit derivatives (Ahmed and Khan 2007). These issues send a signal to regulators to be more proactive in order to promote soundness in the IB system. Some countries, including Malaysia, provide a few facilities, e.g., the Islamic inter-bank money market and specific legal frameworks for exactly this purpose. Yet, the global IB industry needs the collective will of all countries to guard the industry against excessive exposure to risk.

\subsection{Risk Management of Islamic Banks (IBs)}

Risk management is a cornerstone of responsible banking operations. In short, sound risk management principles and effective risk management practices will indirectly increase the profitability of banks and ensure their survival. Acknowledging the need for sound risk management and a corresponding comprehensive risk-management framework, the Basel Committee on Banking Supervision (BCBS) introduced risk guidelines for commercial banks (Abu Hussain and Al-Ajmi 2012). In the wake of the GFC, risk management became even more important. In Rahman and Shahimi (2010) view, risk management is more important in the financial services sector than any other part of the economic system. This is because the existence of a weak risk management system has implications that go far beyond the immediate losses borne by individual banks. Instead, extensive losses in the banking context can lead to the collapse of individual banks and even to the banking system more generally with serious implications for the economy in a broad sense.

Effective risk management protects an organization's assets and profits by reducing the potential for loss and mitigating the impact of loss when it does occur, thereby ensuring a swift recovery (Coffin 2009). According to Galai et al. (1999), financial risk management is the process by which managers identify risks involved in transactions, understand and measure those risks, determine the factors involved in them, and establish and implement procedures to reduce them. Waring and Glendon (1998) as cited in Kalapodas and Thomson (2006) contend that risk management practices are put in place in an effort to eradicate, reduce, and manage risk, and to increase the benefits of while avoiding the harm associated with taking risk. In other words, risk management can be defined as the avoidance of risky activities or when the risk cannot be avoided, transferring the risk to a third party. In a study focused on the determinants of the risk-taking of IBs in seven countries for the period of 2006-2009, Hassan and Mollah (2014) found that the nature of Shariah boards does not seem to limit risk-taking. Conversely, corporate governance and financial disclosure issues are the key factors for risk-taking in IBs.

Risk management is an ongoing process that depends directly on changes in the internal and external environments of banks (Abu Hussain and Al-Ajmi 2012). For IBs, risk management is very complicated because IBs cannot simply replicate the established practices of CBs. However, in terms of the risk management process, IBs are similar to CBs. However, Kayed and Hassan (2011) have argued that the respective risk management processes of IBs and CBs are, in fact, similar, inasmuch as both kinds of banks begin with risk identification, mitigation, and efforts to control exposure to risk in order to maintain profitability. Unlike CBs, however, IBs must ensure that as the framework develops, all the tools used are in line with the requirements of Shariah. In the context of IBs, risk identification is a two-step process: The first is negative Shariah screening, which excludes Riba-, Gharar-, and Maysir-based transactions-this step reduces exposure to risk to a level considered to be appropriate. The second is positive screening, which emphasizes justice, ethics, and accountability issues. Every product offered by an IB must be subjected to the first screening, which is conducted by the bank's Shariah board. 
In Table 4, a summary is presented of the research on risk management as practiced by IBs. In all the studies focused on risk management in IBs to date, as the table shows, a mixed-methods analysis is used. A brief account of each study is also presented in the table. However, we elaborate on some of the most important studies here. For example, Masood et al. (2012) found that IBs in the UAE are more likely to use newer, sophisticated and robust credit risk management techniques of credit risk management than the non-Islamic banks. Abedifar et al. (2013) found that in general, small IBs in majority Muslim states had a lower credit risk than did CBs of a similar size. Most recently, Hassan et al. (2019) published a study on the relationship between liquidity and credit risk by using a simultaneous structural equation approach to 52 IBs and CBs for the period of 2007-2015. They observed that credit risk and liquidity risk have a negative relationship for CBs and for IBs, whereas a negative relationship between liquidity risk and stability is observed only for IBs. The researchers also found that IBs are better risk managers relative to CBs. In our paper, Figure 2 models a detailed breakdown of the risk structure through which IBs mitigate risk.

Table 4. Studies investigating risk management in Islamic banks (IBs).

\begin{tabular}{|c|c|c|c|}
\hline Study & Methodology & Research Questions & Main Results \\
\hline Hassan et al. (2019) & $\begin{array}{l}\text { Simultaneous } \\
\text { structural } \\
\text { equation (SEM) } \\
\text { approach }\end{array}$ & $\begin{array}{l}\text { What is the relationship } \\
\text { between liquidity risk and } \\
\text { credit risk in IBs? } \\
\text { What is the impact of liquidity } \\
\text { risk on bank stability? } \\
\text { What is the performance } \\
\text { difference of IBs and CBs with } \\
\text { respect to liquidity, credit risk, } \\
\text { and bank stability? }\end{array}$ & $\begin{array}{l}\text { There is a negative relationship } \\
\text { between liquidity risk and } \\
\text { stability for only IBs. } \\
\text { Islamic banks are better than } \\
\text { conventional in managing risk. }\end{array}$ \\
\hline Mokni et al.(2015) & $\begin{array}{l}\text { Descriptive } \\
\text { statistics }\end{array}$ & $\begin{array}{l}\text { What is the current state of risk } \\
\text { management among IBs and } \\
\text { CBs in the MENA region? }\end{array}$ & $\begin{array}{l}\text { - Credit risk is considered the } \\
\text { most important for both CBs and } \\
\text { IBs followed by liquidity risk. } \\
\text { CBs and IBs continue to rely on } \\
\text { traditional credit risk } \\
\text { mitigation tools. }\end{array}$ \\
\hline Abedifar et al. (2013) & $\begin{array}{l}\text { Regression } \\
\text { analysis }\end{array}$ & $\begin{array}{l}\text { What is the state of bank credit } \\
\text { and insolvency risk for IBs and } \\
\text { for CBs with Islamic windows? }\end{array}$ & $\begin{array}{l}\text { Small IBs in majority Muslim } \\
\text { states were shown to have a } \\
\text { lower credit risk than did CBs of } \\
\text { a similar size. }\end{array}$ \\
\hline Masood et al. (2012) & $\begin{array}{l}\text { Logistic } \\
\text { regression }\end{array}$ & $\begin{array}{l}\text { What are the differences } \\
\text { between Islamic and } \\
\text { non-Islamic banks in the UAE } \\
\text { in regard to credit } \\
\text { risk management? }\end{array}$ & $\begin{array}{l}\text { - IBs in the UAE are more likely to } \\
\text { use newer, sophisticated and } \\
\text { robust credit risk management } \\
\text { techniques of credit risk } \\
\text { management than the } \\
\text { non-Islamic banks. }\end{array}$ \\
\hline
\end{tabular}


Table 4. Cont.

\begin{tabular}{|c|c|c|c|}
\hline Study & Methodology & Research Questions & Main Results \\
\hline $\begin{array}{l}\text { Abu Hussain and } \\
\text { Al-Ajmi (2012) }\end{array}$ & $\begin{array}{l}\text { Regression } \\
\text { analysis }\end{array}$ & $\begin{array}{l}\text { Do bankers understand risk } \\
\text { and risk management? } \\
\text { Do banks identify the potential } \\
\text { risks to which they } \\
\text { are exposed? } \\
\text { - } \quad \text { Do banks have a system in } \\
\text { place for assessing and } \\
\text { analyzing risk? } \\
\text { Do banks monitor and control } \\
\text { risks efficiently? } \\
\text { Do banks have efficient risk } \\
\text { management strategies } \\
\text { in place? } \\
\text { Do banks examine credit } \\
\text { risk efficiently? } \\
\text { What types of RI methods do } \\
\text { banks use? } \\
\text { What types of risks are banks } \\
\text { exposed to? }\end{array}$ & $\begin{array}{l}\text { Banks in Bahrain have a clear } \\
\text { understanding of risk and risk } \\
\text { management and follow efficient } \\
\text { risk-identification, risk-assessment } \\
\text { analysis, risk-monitoring, credit } \\
\text { risk-analysis and } \\
\text { risk-management practices. } \\
\text { - } \text { IBs differ from their conventional } \\
\text { counterparts in understanding risk } \\
\text { and risk management. } \\
\text { The three most important risks } \\
\text { facing both CBs and IBs are a } \\
\text { credit risk, liquidity risk, and } \\
\text { operational risk. } \\
\text { IBs face greater risk than CBs do. } \\
\text { Country, liquidity, operational, } \\
\text { residual, and settlement risks are } \\
\text { greater for IBs than for CBs. }\end{array}$ \\
\hline Hassan (2011) & $\begin{array}{l}\text { Regression } \\
\text { analysis and } \\
\text { ANOVA }\end{array}$ & $\begin{array}{l}\text { - What is the current state of risk } \\
\text { management in Islamic and } \\
\text { conventional banks in the } \\
\text { Middle East? }\end{array}$ & $\begin{array}{l}\text { - There is a positive relationship } \\
\text { between risk management } \\
\text { practices and understanding risk, } \\
\text { risk management, risk } \\
\text { identification, risk assessment, risk } \\
\text { monitoring, and credit risk } \\
\text { analysis in IBs and CBs. }\end{array}$ \\
\hline Hassan (2009) & $\begin{array}{l}\text { Descriptive } \\
\text { statistics and } \\
\text { regression } \\
\text { analysis }\end{array}$ & $\begin{array}{l}\text { - What are the main risks faced } \\
\text { by IBs in Brunei? } \\
\text { To what extent do IBs in Brunei } \\
\text { engage in risk management } \\
\text { practices (RMP) and what are } \\
\text { the techniques used? }\end{array}$ & $\begin{array}{l}\text { - Brunei IBs face three main types of } \\
\text { risks: foreign exchange risk, credit } \\
\text { risk, and operating risk. }\end{array}$ \\
\hline Siddiqui (2008) & $\begin{array}{l}\text { Literature } \\
\text { review } \\
\text { comparisons } \\
\text { Ratio analysis }\end{array}$ & $\begin{array}{l}\text { What are the main IFS } \\
\text { contracts used by IBs } \\
\text { in Pakistan? } \\
\text { - What are the main causes of } \\
\text { risk faced by IBs? }\end{array}$ & $\begin{array}{l}\text { - IBs in Pakistan are mostly used for: } \\
\text { (i) Murabahah } \\
\text { (ii) Ijarah } \\
\text { (iii) Mudharabah and } \\
\text { Musharakah } \\
\text { Mudharabah and Musharakah are } \\
\text { associated with various } \\
\text { investment risks where } \\
\text { information is asymmetric. These } \\
\text { risks later lead to moral hazard } \\
\text { and adverse selection issues. }\end{array}$ \\
\hline
\end{tabular}


Table 4. Cont.

\begin{tabular}{|c|c|c|c|}
\hline Study & Methodology & Research Questions & Main Results \\
\hline $\begin{array}{l}\text { Al-Tamimi and } \\
\text { Al-Mazrooei (2007) }\end{array}$ & $\begin{array}{l}\text { Descriptive } \\
\text { statistics and } \\
\text { regression } \\
\text { analysis }\end{array}$ & $\begin{array}{l}\text { What are the main risks faced } \\
\text { by IBs in UAE? } \\
\text { How do the different risks } \\
\text { faced by UAE national and } \\
\text { foreign banks compare? }\end{array}$ & $\begin{array}{l}\text { The UAE faces three main } \\
\text { risks: credit risk, operating } \\
\text { risk, and foreign exchange risk. }\end{array}$ \\
\hline $\begin{array}{l}\text { Ahmed and Khan } \\
\text { (2007) }\end{array}$ & Qualitative & $\begin{array}{l}\text { What are the perceptions of } \\
\text { Islamic bankers regarding the } \\
\text { risk inherent in various } \\
\text { IB contracts? }\end{array}$ & $\begin{array}{l}\text { - Credit risk is highest for } \\
\text { Musharakah contracts and } \\
\text { lowest for } \\
\text { Murabahah contracts. } \\
\text { Liquidity risk is highest for } \\
\text { diminishing Musharakah } \\
\text { contracts and lowest } \\
\text { for Mudharabah. } \\
\text { Market risk is highest for } \\
\text { Musharakah contracts and } \\
\text { lowest for Murabahah and } \\
\text { Istisna contracts. }\end{array}$ \\
\hline
\end{tabular}

Given the rapid global growth of the IB industry, it is important for IBs to have appropriate risk management frameworks and processes in place. Before the establishment of the Islamic Financial Services Board (IFSB) in 2005, IBs did not have any specific risk management frameworks or guidelines. The risk management activities of IBs depended on the initiatives of the banks themselves or the regulatory bodies of a given country or jurisdiction. For example, in Malaysia, following the establishment of IBs, all banks followed the framework used by their conventional counterparts especially in the context of ensuring adequate capital. A growing awareness that the IB system required its own risk management framework led to the establishment of the IFSB.

\section{Credit Risk of Islamic Banks (IBs)}

In this section, we investigate the credit risk profiles of Islamic Banks (IBs) in ASEAN countries as the main risk faced by these countries. However, due to limitations in regard to the data available, the discussion focuses on Malaysian IBs (MIBs). IBs have operated in Malaysia for a very long time, which provides a basis for investigating the determinants of credit risk for Malaysian Banks.

We investigate the determinants of credit risk for 19 Malaysian Islamic banks (MIBs) based on data that we collected from the financial statements and annual reports of each of these banks. We used credit risk as a dependent variable with credit risk measured using the ratio of non-performing financing (NPF) to total financing (TF) for each bank. Eight independent variables as used in the literature (Ahmad and Ariff 2007; Louzis et al. 2012; Misman et al. 2015; Salas and Saurina 2002) and one dummy was regressed with the dependent variable to identify the key credit risk determinants for MIBs. Among the variables are loan expansion, loan quality, capital buffer, capital ratio, costs of the fund, management efficiency, and bank size (See the Appendix A for definitions). A panel dataset was used to identify the factors that impact the extent of the various kinds of credit risk faced by MIBs. The multivariate model we estimated is specified as follows:

$$
\begin{gathered}
\mathrm{CR}=f(\mathrm{TL}, \mathrm{LQ}, \mathrm{CB}, \mathrm{CAP}, \mathrm{FCOST}, \text { MGT EFF, TA, FOREIGN }) \\
\mathrm{CR}_{\mathrm{it}}=\beta 0+\beta 1 \mathrm{CR}_{\mathrm{it}-1}+\beta 2 \mathrm{TL}_{\mathrm{it}}+\beta 3 \mathrm{LQ}_{\mathrm{it}}+\beta 4 \mathrm{CB}_{\mathrm{it}}+\beta 5 \mathrm{CAP}_{\mathrm{it}}+\beta 6 \mathrm{FCOST}_{\mathrm{it}}+ \\
\beta 7 \mathrm{MGT} \mathrm{EFF}_{\mathrm{it}}+\beta 8 \mathrm{Log}(\mathrm{TA})_{\mathrm{it}}+\beta 9 \mathrm{FOREIGN}_{\mathrm{it}}+\varepsilon_{\mathrm{it}}
\end{gathered}
$$

where credit risk (CR) is non-performing loans to total loans outstanding; loan expansion (TL) is total loans to total assets; $\mathrm{CR}_{\mathrm{it}-1}$ is a one-year lag of $\mathrm{CR}$; loan quality (LQ) is loan loss provisions to total assets; capital buffer (CB) is total equity to total assets; capital ratio (CAP) is total capital 
(Tier 1 and Tier 2 capital) to total assets ratio; cost of funds (FCOST) is interest expenses to total assets; management efficiency (MGT EFF) is earning assets to total assets; size (TA) is the natural logarithm of total assets; FOREIGN is a dummy with a value of 1 for a foreign IB and 0 otherwise.

We performed the analysis using unbalanced panel data for the period of 2000 to 2016. The total number of observations was 203 for the model. White (1980) cross-section was used to adjust the standard errors for the possible occurrence of heteroskedasticity. We also checked for multicollinearity using the variance inflation factor (VIF). In our models, VIF ranges from 1.24 to 3.15 with a mean value of 2.03. This value range indicates that multicollinearity is not a concern in our models, as it is commonly held that further investigation is needed for VIF greater than 4 and correction required for VIF greater than 7 (Akguc and Rahahleh 2018).

We estimated Model 1 using the fixed-effect (FE), the pooled OLS method, and generalized least square (GLS) with random effects. Table 5 presents the results for the estimation models. For example, Model 1 with FE presents the results of eight BSVs and the explanatory power of the results is about $74.5 \%$ with six BSVs with significant effects on credit risk at the $1 \%$ and $10 \%$ significance level.

Table 5. Regression results for bank-specific variables (BSV) and ownership status regarding credit risk.

\begin{tabular}{|c|c|c|c|}
\hline Independent Variables & (1) & (2) & (3) \\
\hline & Fixed Effect & OLS & GLS-Random Effect \\
\hline $\mathrm{C}$ & $\begin{array}{c}-25.514 \text { *** } \\
(-3.21)\end{array}$ & $\begin{array}{c}-15.213^{* * *} \\
(-2.17)\end{array}$ & $\begin{array}{c}-19.546^{* * *} \\
(-3.15)\end{array}$ \\
\hline $\mathrm{CR}_{\mathrm{t}-1}$ & $\begin{array}{c}0.491^{* * *} \\
(10.94)\end{array}$ & $\begin{array}{c}0.654^{* * *} \\
(5.59)\end{array}$ & $\begin{array}{c}0.589 * * * \\
(14.26)\end{array}$ \\
\hline TL & $\begin{array}{c}-0.048^{* *} \\
(-2.36)\end{array}$ & $\begin{array}{l}-0.028 \\
(-1.19)\end{array}$ & $\begin{array}{c}-0.039 * * \\
(-2.11)\end{array}$ \\
\hline LQ & $\begin{array}{c}0.461^{* * *} \\
(4.26)\end{array}$ & $\begin{array}{c}0.424^{* * *} \\
(2.44)\end{array}$ & $\begin{array}{c}0.431^{* * *} \\
(4.38)\end{array}$ \\
\hline CB & $\begin{array}{c}0.452^{* * *} \\
(4.91)\end{array}$ & $\begin{array}{c}0.302^{* * * *} \\
(4.60)\end{array}$ & $\begin{array}{c}0.336^{* * * *} \\
(5.44)\end{array}$ \\
\hline CAP & $\begin{array}{c}-0.127^{* * *} \\
(-3.04)\end{array}$ & $\begin{array}{l}-0.048 \\
(-1.27)\end{array}$ & $\begin{array}{l}-0.077 * \\
(-1.94)\end{array}$ \\
\hline FCOST & $\begin{array}{l}0.065 \\
(0.42) \\
\end{array}$ & $\begin{array}{l}-0.023 \\
(-0.22) \\
\end{array}$ & $\begin{array}{l}0.021 \\
(0.19) \\
\end{array}$ \\
\hline MGT EFF & $\begin{array}{l}0.022 \\
(1.21)\end{array}$ & $\begin{array}{l}0.018 \\
(1.15)\end{array}$ & $\begin{array}{l}0.023 \\
(1.36)\end{array}$ \\
\hline TA & $\begin{array}{c}1.774^{* * *} \\
(3.67)\end{array}$ & $\begin{array}{c}0.989 * * * \\
(2.29)\end{array}$ & $\begin{array}{c}1.311^{* * *} \\
(3.45)\end{array}$ \\
\hline FOREIGN & $\begin{array}{l}-0.401 \\
(-0.23)\end{array}$ & $\begin{array}{l}-0.127 \\
(-0.18)\end{array}$ & $\begin{array}{l}0.135 \\
(0.16)\end{array}$ \\
\hline $\mathbf{R}^{2}$ & 0.604 & 0.736 & 0.745 \\
\hline $\mathbf{N}$ & 203 & 203 & 203 \\
\hline
\end{tabular}

Table 5 presents regressions of credit risk on bank-specific variables (BSVs) in Malaysia. The data are from BankScope database. The dependent variable is credit risk calculated as the ratio of non-performing financing (NPF) to total financing (TF) for each bank. The numbers in parentheses are the standard errors adjusted for heteroskedasticity and covariance using White's cross-sections. ${ }^{* * *},{ }^{* *},{ }^{*}$ represent significance at the $1 \%, 5 \%$, and $10 \%$ levels, respectively. (See Appendix A for definitions of the variables.).

Table 5 shows that the coefficient of $\mathrm{CR}_{\mathrm{it}-1}$ is positive. This result is in line with the empirical results reported by Salas and Saurina (2002). Further, Table 5 shows that financing (loan) expansion has a negative impact on credit risk in the FE and GLS-RE estimation models. This negative significant result is consistent with results reported by Rahman and Shahimi (2010). 
As expected, financing quality has a positive significant impact on credit risk regardless of the specification and estimation model. This variable is highly significant in determining credit risk, as all the coefficients are significant at the $1 \%$ level. These results are not surprising, as more provisions for loss indicate that a bank may have a problem with financing quality. Thus, the bank will increase its exposure to credit risk. In other words, a downgrade in financing quality will potentially increase the risk of default.

In regard to capital buffer (i.e., the ratio of total equity to total assets), in previous studies, overall mixed results are reported pertaining to the relationship between CB and CR (e.g., Cebenoyan and Strahan 2004; Godlewski 2005). For example, Godlewski (2005) found a positive significant relationship between equity and risk, whereas Cebenoyan and Strahan (2004) reported a negative relationship between a capital buffer and credit risk. Table 5 shows that capital buffer has a significant positive impact on credit risk for all the estimation models in the present study. Having a positive sign means that IBs with more equity capital tend to have higher credit risk than do banks with less equity. Put differently, compared with banks with less equity capital, those with more equity capital are more likely to engage in more risky financing activities as the latter believe that they have sufficient capital to buffer potential losses.

In terms of the capital ratio (CAP) calculated as a ratio of total capital (Tier 1 and Tier 2 capital) to total assets, the coefficient is negative and statistically significant in both the FE and GLS-RE estimation models. This result indicates that the more regulatory capital held by the IBs, the less they are exposed to credit risk. Put differently, a prudent capital management policy plays a role in reducing the level of problem financing and managing risk exposure in MIBs. Bank Negara Malaysia (i.e., the country's central bank) developed a capital-adequacy framework for IBs (CAFIB) to safeguard their risk management practices. In fact, the Basel Committee on Banking Supervision (BCBS) introduced the capital-adequacy framework to promote soundness and stability in the financial system by discouraging banks from engaging in excessively risky activities (Basel 1999). Given that they are effective in managing risk exposure, this framework is in line with our results.

In regard to the relationship between size and credit risk, our results indicate that size has a positive significant effect on credit risk level for all the models used in this study. This result is in line with a result reported by Ahmad and Ariff (2007), who found a positive relationship between size and credit risk for CBs in Korea, Mexico, India, Thailand, Australia, and France.

In regard to the cost of funds (FCOST) and management efficiency (MGT EFF), we did not find any significant relationships between credit risk and either of these two variables in any of the estimations. We further examined the impact of the FOREIGN dummy on the credit risk level of IBs in Malaysia. Our results show that FOREIGN dummy is not significant for any of the models tested.

To summarize, we found that financing expansion (TL), loan quality (LQ), capital buffer (CB), size (TA), and one-year lagged credit risk (CR) demonstrated consistent results regardless of regression specifications or estimation model. These results suggest that any deterioration in financing quality forces MIBs to allocate more extensive loss provisions, and consequently increase the implied credit risk level. The results also show that banks with more equity capital are more likely to engage in more risky financing activities as compared with banks with less equity capital. Also, we found evidence suggesting that TL and CAP each has a significantly negative impact on the credit risk level of MIBs.

\section{Conclusions}

In this paper, we discussed the structures and fundamental features of Islamic banking. We also reviewed the main characteristics of IBs in comparison with the main characteristics of CBs. Further, we discussed the types of risks faced by IBs, the characteristics of those risks, and the differential exposure to those risks as compared with CBs. We also examined the determinants of the credit risk of IBs in Malaysia (MIBs). A summary of our most important results related to the main characteristics of IBs compared to CBs is as follows: 
1. The operations of IBs must conform with Shariah principles. IBs differ from CBs in that IBs operate free from interest, uncertainty, and gambling (Khir et al. 2008).

2. The five most important pillars of Islamic banking can be summarized as follows: prohibition of Riba, sharing of equity contributions, money as a medium of exchange (Gharar), and purity of contract. In IB operations, all products and services are offered based on three main types of contracts: trading contract, participation contract, and supporting contract (Khir et al. 2008).

3. Although Islamic law in the Islamic banking system forbids an interest element, capital is not "costless." Capital is recognized as a production input in Islamic law (Ariff 1988), and profit-sharing is a viable alternative to interest (Kahf 1999).

4. There is a lack of Shariah expertise and a weak legal framework, which results in weak support for Shariah-based product development.

5. The financial statements of IBs differ from those generated by CBs. For example, cash in IBs refers strictly to cash items, whereas cash in CBs usually consists of cash and other interest-bearing assets (AAOIFI and CB).

6. Small IBs may face less risk than similar sized CBs (Abedifar et al. 2015).

7. Both IBs and CBs face risks in their daily operations. CBs face five types of risks: credit risk, interest rate risk, liquidity risk, underwriting risk, and operating risk (Saunders and Cornett 2006). IBs face financial risk, business risk, treasury risk, and governance risk (Iqbal and Mirakhor 2007).

8. We propose a framework for grouping the risks faced by IBs by considering a systematic and unsystematic risk classification. In the proposed framework, only business risk is considered a systematic risk. Governance risk is classified under unsystematic risk, whereas financial risk and treasury risk are classified under SUR as having the ability to be either or un.

9. IBs are unique in regard to risk-related issues. For example, IBs face two types of risks: risks similar to those faced by CBs and risks that are unique because IBs comply with Shariah (Ahmed and Khan 2007).

10. The risk of compliance with Shariah entails two types of risks (Makiyan 2008): risk related to PLS contracts and risk relate to legal and corporate governance. Čihák and Hesse (2010) provide an explanation for the unique nature of risk in the Islamic banking context by asserting that IB risk derives not only from the specific nature of the PLS and NPLS contracts, but is also due to the legal, governance, and liquidity infrastructure of Islamic finance.

11. The relationship between IBs and their customers is not just one between lender and borrower but also that of investor and entrepreneur. This relationship results in IBs hazarding more risk than CBs. For instance, Mudharabah financing as a default payment by the entrepreneur cannot be established until the contract has expired.

12. Risk management became more important after the GFC. Rahman and Shahimi (2010) support the conclusion that a weak risk management system has a severe impact on profitability and will lead to bank collapse.

13. Bank capital and financing expansion have a significant negative impact on the credit risk level of IBs in Malaysia. Further, financing quality (LQ), capital buffer (CB), size (TA), and lagged $\mathrm{CR}$ demonstrate a positive impact on credit risk regardless of regression specifications or estimation model.

Author Contributions: N.A.R., M.I.B., and F.N.M. have contributed jointly to all of the sections of the paper.

Funding: This research received no external funding.

Conflicts of Interest: The authors declare no conflict of interest. 


\section{Appendix A}

Table A1. Variables of interest.

\begin{tabular}{ll}
\hline Credit risk (CR) & Non-performing loans to total financing outstanding \\
\hline Financing expansion (TL) & Total loans to total assets \\
\hline Quadratic term of financing expansion $\left(\mathrm{TL}^{2}\right)$ & Squared value of TL \\
\hline Loan quality (LQ) & Loan loss provisions to total assets \\
\hline Capital buffer (CB) & Total equity to total assets \\
\hline Capital ratio (CAP) & Total capital (Tier 1 and Tier 2 capital) to total assets ratio \\
\hline Cost of funds (FCOST) & Interest expenses to total assets \\
\hline Management efficiency (MGT EFF) & Earning assets to total assets \\
\hline Size (TA) & Natural logarithm of total assets \\
\hline FOREIGN dummy & Value $=1$ for a foreign Islamic bank \\
\hline
\end{tabular}

\section{References}

Abedifar, Pejman, Philip Molyneux, and Amine Tarazi. 2013. Risk in Islamic banking. Review of Finance 17: $2035-96$. [CrossRef]

Abedifar, Pejman, Shahid M. Ebrahim, Philip Molyneux, and Amine Tarazi. 2015. Islamic banking and finance: Recent empirical literature and directions for future research. Journal of Economic Surveys 29: 637-70. [CrossRef]

Abu Hussain, Hameeda, and Jasim Al-Ajmi. 2012. Risk management practices of conventional and Islamic banks in Bahrain. The Journal of Risk Finance 13: 215-39. [CrossRef]

Ahmad, Nor Hayati, and Mohamed Ariff. 2007. Multi-country study of bank credit risk determinants. International Journal of Banking and Finance 5: 135-52.

Ahmed, Habib. 2011. Risk Management Assessment Systems: An Application to Islamic Banks. Islamic Research $\mathcal{E}$ Training Institute (IRTI) 19: 63-86.

Ahmed, Habib, and Tariqullah Khan. 2007. Risk Management in Islamic Banking. In Handbook of Islamic Banking. Edited by M. Kabir Hassan and Mervyn K. Lewis. Cheltenham: Edward Elgar Publishing Limited, pp. 144-58.

Akguc, Serkan, and Naseem Al Rahahleh. 2018. Effect of Shariah Compliance on Operating Performance: Evidence from GCC Countries. Emerging Markets Finance and Trade 54: 1-23. [CrossRef]

Akkizidis, Ioannis, and Sunil Kumar Khandelwal. 2008. Financial Risk Management for Islamic Banking and Finance. New York: Palgrave Macmillan.

Al-Tamimi, Hussein A. Hassan, and Faris Mohammed Al-Mazrooei. 2007. Banks' Risk Management: A Comparison Study of Uae National and Foreign Banks. The Journal of Risk Finance 8: 394-409. [CrossRef]

Apostolik, Richard, Christopher Donohue, and Peter Wnet. 2009. Foundations of Banking Risk: An Overview of Banking, Banking Risks and Risk-Based Banking Regulation. Hoboken: John Wiley \& Sons Inc.

Archer, Simon, and Rifaat Ahmed Abdel Karim. 2009. Profit-Sharing Investment Accounts in Islamic Banks: Regulatory Problems and Possible Solutions. Journal of Banking Regulation 10: 300-6. [CrossRef]

Ariff, Mohamed. 1988. Islamic Banking. Asian-Pacific Economic Literature 2: 48-64. [CrossRef]

Ayub, Muhammad. 2007. Understanding Islamic Finance. Chichester: John Wiley \&Sons Ltd.

Basel. 1999. Principles for the Management of Credit Risk. Basel: Basel Committee on Banking Supervision.

Basel. 2003. The New Basel Capital Accord. Basel: Basel Committee on Banking Supervision.

Beck, Thorsten, Asli Demirgüç-Kunt, and Ouarda Merrouche. 2013. Islamic vs. conventional banking: Business model, efficiency and stability. Journal of Banking and Finance 37: 433-47. [CrossRef]

Carey, Mark, and Rene M. Stulz. 2005. The Risks of Financial Institutions. Working Paper No. 11442. Cambridge: National Bureau of Economic Research. 
Cebenoyan, A. Sinan, and Philip E. Strahan. 2004. Risk management, capital structure and lending at banks. Journal of Banking E Finance 28: 19-43.

Cerović, Ljerka, Stella Suljić Nikolaj, and Dario Maradin. 2017. Comparative analysis of conventional and Islamic banking: Importance of market regulation. Ekonomska Misao i Praksa 1: 241-63.

Chong, Beng Soon, and Ming-Hua Liu. 2009. Islamic banking: interest-free or interest-based? Pacific-Basin Finance Journal 17: 125-44. [CrossRef]

Čihák, Martin, and Heiko Hesse. 2010. Islamic Banks and Financial Stability: An Empirical Analysis. Journal of Financial Services Research 38: 95-113. [CrossRef]

Coffin, Bill. 2009. The 2008 Financial Crisis: A Wake-up Call for Enterprise Risk Management. New York: Risk and Insurance Management Society, Inc. Available online: http / /:www.community.rims.org/RIMS (accessed on 15 September 2018).

El Massah, Suzanna, and Ola Al Sayed. 2015. Banking sector performance: Islamic and conventional banks in the UAE. International Journal of Information Technology and Business Management 36: 69-81.

Galai, Dan, David Ruthenberg, Marshall Sarnat, and Ben Z. Schreiber, eds. 1999. Risk Management and Regulation in Banking. Boston: Kluwer Academic Publishers.

Godlewski, Christophe J. 2005. Bank Capital and Credit Risk Taking in Emerging Market Economies. Journal of Banking Regulation 6: 128-45. [CrossRef]

Greuning, Hennie Van, and Zamir Iqbal. 2008. Risk Analysis for Islamic Banks. Washington, DC: The World Bank.

Hanif, Muhammad, and Abdullah Iqbal. 2010. Islamic Financing and Business Framework: A Survey. European Journal of Social Sciences 15: 475-89.

Hassan, Abul. 2009. Risk Management Practices of Islamic Banks of Brunei Darussalam. The Journal of Risk Finance 10: 23-37. [CrossRef]

Hassan, Wael Moustafa. 2011. Risk management practices: A comparative analysis between Islamic banks and conventional banks in the Middle East. International Journal of Academic Research 3: 288-95.

Hassan, M. Kabir, and Sirajo Aliyu. 2018. A contemporary survey of Islamic banking literature. Journal of Financial Stability 34: 12-43.

Hassan, M. Kabir, and Mehmet F. Dicle. 2005. Basel II and regulatory framework for Islamic banks. Journal of Islamic Economics, Banking and Finance 1: 1-16.

Hassan, M. Kabir, and Sabur Mollah. 2014. Corporate Governance, Risk Taking and Firm Performance of Islamic Banks during Global Financial Crisis. Working Paper. New Orleans: University of New Orleans.

Hassan, M. Kabir, Sirajo Aliyu, Andrea Paltrinieri, and Ashraf Khan. 2018. A Review of Islamic Investment Literature. Economic Papers: A Journal of Applied Economics and Policy. [CrossRef]

Hassan, M. Kabir, Ashraf Khan, and Andrea Paltrinieri. 2019. Liquidity risk, credit risk and stability in Islamic and conventional banks. Research in International Business and Finance 48: 17-31. [CrossRef]

Iqbal, Munawar. 2011. Development, History and Prospects of Islamic Banking. In The Foundations of Islamic Banking: Theory, Practice and Education. Edited by Mohamed Arif and Munawar Iqbal. Cheltenham: Edward Elgar Publishing Limited.

Iqbal, Zamir, and Abbas Mirakhor. 2007. An Introduction to Islamic Finance: Theory and Practice. Singapore: John Wiley \& Son (Asia).

Kahf, Monzer. 1999. Islamic Banks at the Threshold of the Third Millennium. Thunderbird International Business Review 41: 445-60. [CrossRef]

Kalapodas, Evangelos, and Mary E. Thomson. 2006. Credit Risk Assessment: A Challenge for Financial Institutions. IMA Journal of Management Mathematics 17: 25-46. [CrossRef]

Kayed, Rasem N, and M. Kabir Hassan. 2011. The Global Financial Crisis and Islamic Finance. Thunderbird International Business Review 53: 551-64. [CrossRef]

Khalid, Sania, and Shehla Amjad. 2012. Risk management practices in Islamic banks of Pakistan. The Journal of Risk Finance 13: 148-59. [CrossRef]

Khan, Tauseef, Waqar Ahmad, Muhammad Khalil Ur Rahman, and Fazal Haleem. 2018. An investigation of the performance of Islamic and interest based banking evidence from Pakistan. HOLISTICA-Journal of Business and Public Administration 9: 81-112. [CrossRef]

Khir, Kamal, Lokesh Gupta, and Bala Shanmugam. 2008. Islamic Banking: A Practical Perspective. Kuala Lumpur: Pearson Longman. 
Laldin, Mohamad Akram. 2008. Islamic Financial System: The Malaysian Experience and the Way Foward. Humanomics 24: 217-38. [CrossRef]

Lewis, Mervyn K. 2011. Ethical Principles in Islamic Business and Banking Transactions. In The Foundations of Islamic Banking: Theory, Practice and Education. Edited by Mohamed Ariff and Munawar Iqbal. Cheltenham: Edward Elgar Publishing Limited.

Louzis, Dimitrios P., Angelos T. Vouldis, and Vasilios L. Metaxas. 2012. Macroeconomic and bank-specific determinants of non-performing loans in Greece: A comparative study of mortgage, business and consumer loan portfolios. Journal of Banking \& Finance 36: 1012-27.

Lucia, Ray De, and John Peters. 1993. Commercial Bank Management: Functions and Objectives, 3rd ed. Hornsby: Serendip Publication.

Makiyan, Seyed Nezamuddin. 2008. Risk Management and Challenges in Islamic Banks. Journal of Islamic Economics, Banking and Finance 4: 45-54.

Masood, Omar, Hasan Al Suwaidi, and Priya Darshini Pun Thapa. 2012. Credit risk management: a case differentiating Islamic and non-Islamic banks in UAE. Qualitative Research in Financial Markets 4: 197-205. [CrossRef]

Misman, Faridah Najuna, Ishaq Bhatti, Weifang Lou, Syamsyul Samsudin, and Nor Hadaliza Abd Rahman. 2015. Islamic banks credit risk: A panel study. Procedia Economics and Finance 31: 75-82. [CrossRef]

Mokni, Rim Ben Selma, Abdelghani Echchabi, and Mohamed Taher Rajhi. 2015. Risk management practiced tools in the MENA region: A comparative study between islamic and conventional banks. International Journal of Business 20: 261.

Oldfield, George S., and Anthony M. Santomero. 1997. Risk Management in Financial Institutions. Sloan Management Review 39: 33-47.

Olson, Dennis, and Taisier Zoubi. 2017. Convergence in bank performance for commercial and Islamic banks during and after the Global Financial Crisis. The Quarterly Review of Economics and Finance 65: 71-87. [CrossRef]

Pappas, Vasileios, Stephen Ongena, Marwan Izzeldin, and Ana-Maria Fuertes. 2014. Do Islamic Banks' Live Free and Die Harder? Paper presented at the Seminar on Finance and Development in Muslim Economies, Bangor, UK, September 15.

Rahman, Aisyah Abdul, and Shahida Shahimi. 2010. Credit Risk and Financing Structure of Malaysian Islamic Banks. Journal of Economic Cooperation and Development 31: 83-105.

Ray, Nicholas Dylan. 1995. Arab Islamic Banking and the Renewal of Islamic Law. London and Boston: Graham \& Trotman.

Rosly, Saiful Azhar. 1999. Al Bay'bithaman Ajil Financing: Impacts on Islamic Banking Performance. Thunderbird International Business Review 41: 461-80. [CrossRef]

Saeed, Momna, and Marwan Izzeldin. 2016. Examining the relationship between default risk and efficiency in Islamic and conventional banks. Journal of Economic Behavior E Organization 132: 127-54.

Safiullah, Md, and Abul Shamsuddin. 2018. Risk in Islamic banking and corporate governance. Pacific-Basin Finance Journal 47: 129-49. [CrossRef]

Salas, Vicente, and Jesus Saurina. 2002. Credit risk in two institutional regimes: Spanish commercial and savings banks. Journal of Financial Services Research 22: 203-24. [CrossRef]

Salih, Abdalla, Mahieddine Adnan Ghecham, and Sameer Al-Barghouthi. 2018. The impact of global financial crisis on conventional and Islamic banks in the GCC countries. International Journal of Finance E Economics. [CrossRef]

Samad, Abdus, Norman D. Gardner, and Bradley J. Cook. 2005. Islamic Banking and Finance in Theory and Practice: The Experience of Malaysia and Bahrain. The American Journal of Islamic Social Sciences 22: 69-86.

Saunders, A., and Marcia Millon Cornett. 2006. Financial Institutions Management: A Risk Management Approach, 5th ed. New York: McGraw-Hill Irwin.

Siddiqui, Anjum. 2008. Financial Contracts, Risk and Performance of Islamic Banking. Managerial Finance 34: 680-94. [CrossRef]

Sun, Poi Hun, Shamsher Mohamad, and Mohamed Ariff. 2017. Determinants driving bank performance: A comparison of two types of banks in the OIC. Pacific-Basin Finance Journal 42: 193-203. [CrossRef]

Sundararajan, V., and Luca Errico. 2002. Islamic Financial Institutions and Products in the Global Financial System: Key Issues in Risk Management and Challenges Ahead. IMF Working Paper 02. Washington, DC: IMF. 
Tafri, Fauziah Hanim, Rashidah Abdul Rahman, and Normah Omar. 2011. Empirical evidence on the risk management tools practised in Islamic and conventional banks. Qualitative Research in Financial Markets 3: 86-104. [CrossRef]

Waring, Alan E., and A. Ian Glendon. 1998. Managing Risk. Andover: Cengage Learning EMEA.

White, Halbert. 1980. A heteroskedasticity-consistent covariance matrix estimator and a direct test for heteroskedasticity. Econometrica 48: 817-38. [CrossRef] 